\title{
FROM LYRICISM TO DRAMA: THE EVOLUTION OF FERNANDO DE ROJAS' EGOCENTRIC SUBTEXT
}

\author{
Peter Cocozella \\ State University of New York at Binghamtom
}

The critics and literary historians that deal with the Spanish secular theater of the late Middle Ages have not come up yet with a satisfactory account of that theater's distinctive developments. Still unexplained remain the specific traits of the autochthonous literary tradition that came to a head in Fernando de Rojas's acclaimed masterpiece, commonly known as Celestina. A case in point is the monumental La originalidad artística de 'La Celestina', ${ }^{1}$ in which María Rosa Lida de Malkiel leaves no stone unturned in a painstaking reconstruction of Rojas's artistic background. It is fair to point out that, in privileging foreign influences, Lida de Malkiel does not resolve the ultimate question as to how Rojas's authentic Hispanic sources came to be integrated into his own ingenious transformation of the comedia's Terentian, "elegiac," and humanistic phases.

Lida de Malkiel's impressive spadework finds a fitting complement in those recent studies - Ronald E. Surtz's The Birth of a Theater, ${ }^{2}$ Dorothy S. Severin's Tragicomedy and Novelistic Discourse in 'Celestina', ${ }^{3}$ Charles Fraker's 'Celestina': Genre and Rhetoric,' among other

\footnotetext{
${ }^{1}$ Buenos Aires: EUDEBA, 1962, $1970^{2}$.

${ }^{2}$ Madrid: Castalia, 1979.

${ }^{3}$ Cambridge: Cambridge UP, 1989.
} 
- which, in the wake of Stephen Gilman's epoch-making The Art of 'La Celestina', ${ }^{\prime}$ offer fresh insights both into Spanish medieval theater in general and into the theatrical strategies - the nonpareil manipulation of dialogue, for example, and the innovative mise en scène - that in Celestina acquired a dynamism all their own. In this essay, while pursuing the trend of current criticism, $I$ intend to venture into an investigation of Rojas's self-consciousness as a writer. To avoid the pitfalls attendant upon an exploration of such a nebulous, uncharted territory, I will reexamine some key statements proffered by none other than Rojas himself. There is no doubt that the very uniqueness and laconic brevity of these declarations bring to light their paramount significance. Indeed, as I hope to demonstrate, they are fraught with metatextual reflections and implications, which can provide invaluable clues for the definition of Rojas's creative enterprise.

I should like to introduce the concept of egocentrism in order to denote the psychic space that one can envisage at the heart of Hispanic lyricism, prevalent in the cancioneros of the fifteenth century. Arguably, that space is an integral part of the legacy from the troubadours: precisely from the troubadours the cancioneristas and their Catalan counterparts inherited an abiding interest in the definition of the self. They developed, in their own right, an existential stance in unison with an evolving sense of subjectivity - the same subjectivity that Sarah Kay perceptively anatomizes in her recent study, Subjectivity in Troubadour Poetry. ${ }^{6}$ The issues that, as Kay demonstrates, are raised by an in-depth study of subjectivity lie outside the scope of the present discussion. Here the focus is on egocentrism, the inwardness or self-centeredness of subjectivity, which, in the history of Hispanic letters of the quattrocento, mutates, as I hope to show, from a lyrical to a dramatic mode and, ultimately, to a theatrical phenomenon.

As is well known, in 1500 Pedro Hagenbach printed in Toledo one of the earliest extant texts of the sixteen-act version of Celestina, specifically entitled Comedia de Calisto y Melibea. In the preface to this publication, under the heading of "El autor a un su amigo," Rojas included some vague references to "estos papeles" - a codex, that is, of

\footnotetext{
London: Tamesis, 1990.

${ }^{5}$ Madison: U Wisconsin P, 1956.

${ }^{6}$ Cambridge: Cambridge UP, 1990.
} 
unspecified length.? In the acrostic coplas de arte mayor, which also appeared in the 1500 edition, Rojas elaborated upon the aforementioned prefatory statement in many details, including the provenance of the nondescript papeles: "Yo vi en Salamanca la obra presente" (39). In an entire stanza (the sixth, to be exact), he compared, with self-deprecatory modesty, his own additions to the work of the alleged first author. ${ }^{8} \mathrm{He}$ extolled the merits of that work he claimed to have chanced upon: "su primor, su sotil artificio, su fuerte y claro metal, su modo y manera de labor, su estilo elegante, jamás en nuestra castellana lengua visto ni oído" (36). In such model of elegant style and profound insight he saw clear signs of "los claros ingenios de doctos varones castellanos" (36).

${ }^{7}$ The editio princeps of the Comedia is by Fadrique de Basilea (Burgos, 1499). Miguel Marciales provides a full description of this and other basic texts of Rojas's masterpiece. (See Introd., Celestina: Tragicomedia de Calisto y Melibea, by Fernando de Rojas, ed. Miguel Marciales, Illinois Medieval Monographs, 1, I [Urbana and Chicago: University of Illinois Press, 1984], 5-60.) Marciales's extensive list includes under the label " $C$ " the following essential details pertaining to the edition I refer to above: "Toledo. 1500. Pedro Hagenbach. Ejemplar único en la Biblioteca Martín Bodmer, Cologny-Ginebra. Localizado en 1929. Reproducción facsimilar hecha por la Biblioteca Martín Bodmer (ColognyGinebra, 1961). Contenido igual a $B$, pero la octava-colofón modificada Toledo en lugar de Salamanca" (1:6).

Marciales's painstaking analysis of C's distinctive characteristics is found on pp. 30-41. As for "B", Marciales highlights the following data: "Salamanca, mayo/junio 1500. Juan Gysser (?). Perdida. Primera edición "acabada," es decir con Título, Subtítulo, Carta a un amigo, once octavas acrósticas, Incipit, Argumento General, Argumentos para cada auto, 16 autos, seis octavas finales de Proaza" (I:5).

Apropos of the textual problems attendant upon both the Comedia and the Tragicomedia by Fernando de Rojas, particularly useful is the handy overview found in Morón Arroyo Sentido y forma de La Celestina, $2^{2}$ ed. (Madrid: Estudios Cátedra, 1984), pp. 13-17.

Throughout this essay for my quotations from and references to the text of the Comedia I make use of D. S. Severin's edition ( ${ }^{\mathrm{a}} \mathrm{ed}$., El libro de bolsillo 200 [Madrid: Alianza Editorial, 1971]). For "El autor a un su amigo" see pp. 35-37.

8 The copla reads as follows:

Este mi deseo, cargado de antojos

Compuso tal fin que el principio desata:

Acordó de dorar con oro de lata

Lo más fino oro que vio con sus ojos.

$\mathrm{Y}$ encima de rosas sembrar mil abrojos.

Suplico, pues, suplan discretos mi falta.

Teman groseros y en obra tan alta

$O$ vean y callen o no den enojos. (38) 
Evidently, Rojas wasted no effort in identifying the "docto varón" in question. A little further on, in a variant integrated into a later edition of Celestina, he added sparse details, enticing but inconclusive, about the latter: "el cual, según algunos dicen, fue Juan de Mena, y según otros, Rodrigo Cota" (36).

It will surprise no one that such an enigmatic attribution should fan, as, indeed, it has done, the fires of controversy among the critics. For decades hispanists have debated whether Rojas actually did find the dialogue he purports to have used as the first act of Celestina. ${ }^{9}$ If we take Rojas's words al pie de la letra, we are faced by another query: Who is, then, the individual that Rojas in another instance calls "antiguo autor" (37)? ${ }^{10}$ Even those critics who marshal compelling arguments concerning the identity of that author would agree, I believe, that it is very difficult, if not altogether impossible, to coax from Rojas's "El autor a un su amigo" or from the concomitant acrostics a clear answer to these fundamental questions. ${ }^{11}$

${ }^{9}$ In this respect Rojas's indications are very precise: "Y porque conozcáis dónde comienzan mis maldoladas razones, acordé todo lo del antiguo autor fuese sin división en un auto o cena incluso, hasta el segundo auto, donde dice: «Hermanos míos», etc. Vale" (37).

${ }^{10}$ In the "Prólogo" proper Rojas refers to the "primer autor" (43).

${ }^{11}$ For a concise survey on the current status of this controversy, see Morón Arroyo, Sentido y forma, pp. 17-21. As for the authorship of Celestina, see, also, the reexamination and updating of the question in Luis Rubio García, Estudios sobre La Celestina (Murcia: Departamento de Filología Románica, Universidad de Murcia, 1985), pp. 9-22, 25-31, 245-252. After observing that "Hoy no existe documentación segura para dar conclusiones definitivas" (Sentido y forma, p. 17), Morón Arroyo acknowledges the possibility of Cota's authorship (Sentido y forma, p. 20) but finds more plausible the attribution of the papeles to a cleric such as the Arcipreste de Talavera: "El primer acto parece obra de un eclesiástico. Alguien que sentía hondas afinidades con el Arcipreste de Talavera y supo encamar en un diálogo vivo dolores e intereses humanos interpretados y valorados desde un preciso esquema escolástico" (Sentido y forma, p. 21).

The additional data adduced by Michael Gerli ("Celestina, Act I, Reconsidered: Cota, Mena ... or Alfonso Martínez de Toledo?," Kentucky Romance Quarterly, 23 [1976], 29-46") and Anthony J. Cárdenas ("The 'conplisiones de los onbres' of The Arcipreste de Talavera and the Male Lovers of the Celestina," Hispania, 71 [1988], 479-491) corroborate the argument in favor of the Arcipreste's authorship of the auto in question. By a rigorous analysis of the internal philological evidence and by a meticulous re-evaluation of the archival data available, Marciales (pp. 30-41, 269-279) builds up, for his part, an impressive case in favor of Cota's authorship 
Ironically, by virtue of its immediate, startling repercussions, Rojas's statements have been diverting attention from the pivotal issues they might have raised from the very start. In the light of the available evidence, the controversy revolving around the search for the docto varón comes to a dead end. Confronted with the cul-de-sac, we should find it useful to consider the possibility of a new approach to Rojas's extraordinary confession. Doubtless, Rojas raises the issue of who's who. We suspect, though, that he cannot be primarily interested in the identity of an individual, whose name, to paraphrase Cervantes, he does not wish to remember, anyway. After all, for reasons critics still have not been able to fathom, Rojas could not, or, as it seems more likely, would not oblige us with a definitive identification. He, we begin to realize, is concerned not with the discovery of a person of flesh and blood but, rather, with the evocation of an authorial persona.

Arguably, as an adumbration of that persona, the docto varón becomes significant as a purveyor of a new kind of textuality. Rojas foreshadows Cervantes in devising a strategy, which, by means of a forerunner of Cide Hamete Benengeli, rivets our imagination upon the literary composition in the making. Thus the docto varón relates to Celestina in much the same fashion as does Cide Hamete to Don Quijote. At the heart of this Rojas-Cervantes analogy there lies the hypothesis I should like to advance here in its twofold implication. First, contrary to general interpretation, Rojas directs our attention not to the identification of an author but to the definition of a text. Second, in terms of the metatextual dynamics that Rojas sets in operation between himself and the antiguo autor, it makes no difference whether the latter exists as a historical or a fictional being.

of the first auto and the first scene of the second auto of the Comedia. This notwithstanding, by its very byzantine nature, which necessitates such a laborious digestion, Marciales's formidable argumentation confirms my point: the controversy centering upon the aforementioned papeles, which Marciales redefines as Cota's "Esbozo," is far from easy to settle. Antonio Sánchez Sánchez-Serrano and María Remedios Prieto de la Yglesia contrive an intricate theory conceming a supposed original version of Celestina by Juan del Encina, which, according to them, Fernando de Rojas eventually plagiarized and transformed to fit his nottoo-honorable purposes. Rojas, they presume, found a convenient collaborator in the "corrector" Alonso de Proaza. (See Solución razonada para las principales incógnitas de 'La Celestina' [Madrid: Gráficas Breogán, 1971.]) For some comments on this fanciful argument in the light of my own research, see the conclusion of this essay. 
What is distinctive, if not unique, about Fernando de Rojas is the use of factual details as means of introducing the realm of fiction. The mention of easily recognizable literary figures, Mena and Cota, is not in itself an index of historicity but, rather, an integral part of the semiotics that Rojas envisages, or wishes to establish, between himself and his brainchild. Not unlike Cervantes, Rojas has in mind a text, or, to put it more precisely, the prototype of a text, which may function as a springboard for his own imagination. The basic difference between the two authors is that, in the case of Cervantes, we are fairly clear about the nature of the prototype. Cide Hamete leads us straight to the novela de caballerias and, as Menéndez Pidal would have it, to such an odd and intriguing composition as the Entremés de romances. ${ }^{12}$ But what sort of écriture would Rojas ascribe to that elusive, if all-important, docto varón? Is there an undertext, which, in its relation with Celestina, is analogous to the novela de caballerías or the Entremés de romances with respect to Don Quijote?

I believe we can answer the latter question comfortably in the affirmative because Rojas himself helps us identify the salient characteristics of his subtext. In fact, the very mention of Mena and Cota, laconic though it is, turns out to be a poignant obiter dictum, which, when placed in its proper context, leads us right to the mainstream of the lovecentered literature in vogue in Spain during the fifteenth century. The names selected by Rojas, Mena and Cota, stand out as clear references to their respective compositions - namely, Mena's Debate de la Razón contra Voluntad (also known as Coplas contra los pecados mortales) and Cota's Diálogo entre el amor y un viejo. Hispanists would readily recognize these works as highly representative of the aforementioned literature dealing broadly with love and with the lover's condition. ${ }^{13}$ Seeing that, as Lida de Malkiel, Dorothy Clotelle Clarke, and Gladys M. Rivera, among others, have shown, Rojas was familiar with Mena's Debate, we conclude

${ }^{12}$ See De Cervantes y Lope de Vega, 6a ed., Colección Austral, 120 (Madrid: Espasa-Calpe, 1964), Pp. 9-60.

${ }^{13}$ For these two works see, respectively, the edition by Foulché-Delbosc (Cancionero castellano del siglo XV, 2 vols, Nueva Biblioteca de Autores Españoles, 19, 22 [Madrid: Bailly-Bailliére, 1912-15], I, 120-152) and that by Elisa Aragone (Firenze: Felice Le Monnier, 1961). Surtz reedits the Diálogo under the title of Interlocutores Senex et Amor Mulierque Pulcra Forma (cf. Teatro castellano de la Edad Media [Madrid: Clásicos Taurus, 1992], pp. 173-199. See, also, Juan de Mena, Coplas de los siete pecados mortales and First Continuation, ed. Gladys M. Rivera (Madrid: Porrúa Turanzas, 1982), and Rodrigo Cota, Diálogo, in Teatro medieval ed. Fernando Lázaro Carreter (Madrid: Castalia, 1965) pp. 133-154. 
that Rojas appreciated in it precisely what Lida de Malkiel defines as its prominent strain of stoicism. ${ }^{14}$ In line with Lida de Malkiel's comments, we observe that the spirit of stoicism informing the Debate is articulated in terms of an allegory staged within the psyche of the poetic persona. Lida de Malkiel makes it a point to stress this peculiar inner dimension of Mena's allegorical dialectic. First, she sharply defines the Debate's senequismo as the trait of an "alma castigada," deeply affected by the historical circumstance: the dejection precipitated by the deaths of Alvaro de Luna in 1453 and of Juan II in $1454 .^{15}$ Second, she perceives Mena's composition as "una alegoría no montada sobre un esquema cósmico" (Juan de Mena 112). Third, she points out Mena's internalized dramatization by noting that the Debate exhibits "la forma más esquemática de la lucha entre los dos bandos que forman la non simplex natura hominis (...) ensayo de expresar el conflicto interno del alma humana con combates de vaga filiación épica entre estados de conciencia convertidos en figuras alegóricas emparentadas, a su vez, con la máquina mitológica aneja a la epopeya clásica" (Juan de Mena, 112).

There can be little doubt that Rojas was as well acquainted with Cota's Diálogo as he was with Mena's Debate. ${ }^{16}$ Evidently, in that Diálogo

14 See Lida de Malkiel, La originalidad artística, pp. 344, 393 n25, 414 n3, 556 n28; Clarke, Allegory, Decalogue, and Deadly Sins in 'La Celestina' (Berkeley: U California P, 1968), pp. 67-104; Rivera, Introd., Coplas de los siete pecados mortales and First Continuation, by Juan de Mena, ed. Gladys M. Rivera (Madrid: Porrúa Turanzas, 1982), p. 19.

15 Lida de Malkiel, Juan de Mena: poeta del prerrenacimiento español, Publicaciones de la Nueva Revista de Filología Hispánica, 1 (México: Fondo de Cultura Económica, 1950), pp. 110-124. Lida de Malkiel dwells upon the sobering experience that, in the course of the twelve years following the publication of $E l$ Laberinto de Fortuna, brought about a dramatic reorientation in Mena's youthful world view: "Mas esos doce años han asestado terribles golpes a la visión juvenil del poeta. En 1453 muere don Alvaro en el cadalso: increíble caída de príncipe que será debidamente incorporada al elenco De casibus uirorum illustrium de Boccaccio; el cómplice más culpable de su pérdida y de la disgregación feudal de Castilla, el rey don Juan II, muere al año siguiente. Mena (muerto 1456) sobrevivió a ambos. No creo que sea novelar en vacío presumir que el poeta, tan atento al claro programa político intentado por don Alvaro, debió de quedar anonadado. ¡Qué eran las penas de amores del cancionero comparadas con ese desastre que desvanecía de golpe todo el esfuerzo paciente, toda la tenacidad del Condestable para dar unidad a Castilla!" (Juan de Mena, pp. 110-111).

${ }^{16}$ Elisa Aragone, Introd., Diálogo entre el Amor y un Viejo, by Rodrigo Cota, ed. Elisa Aragone (Firenze: Felice Le Monnier, 1961), pp. 50-54. 
Rojas perceived or intuited what various critics - not only Elisa Aragone but also Fernando Lázaro Carreter, ${ }^{17}$ and Ronald E. Surtz ${ }^{18}$ - have assiduously pointed out: its "teatralidad," that is to say, the remarkable reach beyond the dialectic of the slow-motion, and in many instances, stodgy mechanics of the debate; the precise thrust toward the action of a full-fledged theatrical representation. What Rojas finds in Cota is not only the internalization of the dramatic conflict as in Mena's Debate but also the concretization of one of the two antagonists in the characterization of the Old Man as the lover. Aside from the strong tension introduced by the sheer lifelikeness of the dialogue, Rojas discovers his illustrious predecessor's definition of the dramatic situation in terms of El Viejo's shifting attitude toward his interlocutor. The curmudgeon, who, heedless of the lessons that a lifetime of experience would teach him, relapses in the folly of Eros even after he levels some rather harsh reproaches at Amor, is left in a compromised position, replete with ironic, moralistic, and humoristic overtones. These could not be lost on Fernando de Rojas. The very implications of El Viejo's foolhardy recidivism - there is no fool like an old fool! - together with the perspective of the literary tradition which spans from Cota to Rojas are captured by Aragone in a summary statement, which bears quoting in full:

\begin{abstract}
A nostro giudizio, tali reminiscenze [that is, the documented traces of the Diálogo in Celestina] non bastano a comprovare la paternità di R[odrigo] C[ota] riguardo a uno o più atti della Celestina: esse costituiscono una chiara, innegabile testimonianza, della presenza del Diálogo alla mente dell'autore di essa. Ma ben più significativa e importante resta sempre la forza icastica e la vena di pessimismo che circolano nello svolgimento della Tragicomedia memorabile e grandiosa: l'affinità vera e propria - fatte ovviamente, le debite distanze - tra le due opere, poggia su un particolare atteggiamento psicologico comune agli autori. (54)
\end{abstract}

We see, then, that, as he peruses the papeles, Rojas conjures up two stellar figures, Mena and Cota. These, in turn, contribute a nucleus

${ }^{17}$ See Introd., Teatro medieval, ed. Fernando Lázaro Carreter (Madrid: Castalia, 1965), pp. 73-75.

${ }^{18}$ See Introd. ["Estudio preliminar"], Teatro castellano de la Edad Media, ed. Ronald E. Surtz (Madrid: Clásicos Taurus, 1992), pp. 51-54. 
of formal determinants which come to bear upon the notion of a text eminently exemplified in the aforementioned Debate and Diálogo. In defining these determinants - the dynamic or momentum of drama, the introspective intention of the inner conflict, the stoic or senequista mood, the ethical or moralistic orientation, the achievement of a well-rounded characterization by virtue of what Aragone calls "forza icastica" - we begin to catch a glimpse of the field within which Rojas's mind operates. Mena and Cota provide, then, a text embryonically dramatic, the potential of which it is up to Rojas to carry out to full realization by recapturing the impact of that "forza icastica," underscored by Aragone. We may describe Rojas's elaboration of that text as a movement, in Clarke's words, "from the figurative to the literal, from the flat, discrete, although often heavily ornamented, allegorical characters to the fulldimensional, multiple-perspective living beings" (Allegory..., p. 26).

Taking up specifically Rojas's reading of Mena's Debate, Clarke dwells with considerable insight upon the former's elaboration of "the dramatic concept embryonic in the poem and the great number of possibilities of dramatic elaboration it offers" (67). On more that one occasion Clarke manifests her abiding interest in the gradual process of a "humanized" dramatization which issues from allegory and comes to a head in Celestina: "As abstract qualities inevitably came in contact and conflict with each other or were needed in support of each other, drama emerged" (30-31). Capitalizing upon the "teatralidad" that was to become Rojas's crowning achievement, Clarke observes that

the Comedia's author seems to have been much more interested in developing the poet's [Mena's] ideas dramatically than in borrowing his words or incorporating his expressions in the speeches. (67)

It becomes apparent that Clarke is not less impressed than was Lida de Malkiel in Rojas's intuition of interiority:

Like Juan de Mena's poem, however, the Comedia in general is concerned less with exhibition and outward show, and more with inner motivation and psychological process. The Comedia's author was moved far beyond mere surface. Using material available in his time, he plays with tilts and angles and planes, with gradation, and with motion to achieve perspective on both personality and abstract concepts. (108-109) 
A close scrutiny of the literature - especially the lyric poetry of the cancioneros produced in Spain during the fifteenth century - reveals that in this process of dramatization Rojas was guided by a trend set not only by Mena and Cota but also by a number of other writers of his age or of preceding generations. These authors provided for Rojas the groundwork of what I propose to call, for want of a better term, "egocentric subtext." The egocentrism I envisage is, all in one, broad and circumscribed in its signification. It is broad in that it encompasses the self-conscious reflections of the author's persona as portrayed in the guise of the anguished lover not only in the novela sentimental but also in the vast spectrum of the post-troubadouresque lyricism of the late Middle Ages, written both in Castilian and in Catalan. Moreover, it is circumscribed because it is determined by a few core functions, which may be called metaphysical. For instance: inherent in this egocentrism is the interplay, truly at a metaphysical level, between the text's intention toward individuation and its universal projection.

In an attempt to define the texture of egocentrism symptomatic of Hispanic literature of the fifteenth century, which culminates in Rojas's masterpiece, we may identify four basic characteristics. We begin with a notion of interiority, for which I have found no better statement than the one provided in the very conclusion (vv. 59-68) of the "Praefatio" of Prudentius's Psychomachia. Prudentius presents a vision of Christ who "parvam pudici cordis intrabit casam" (v. 62) and speaks of the Holy Spirit wedded to the soul in fruitful embrace: "animam deinde Spiritus complexibus / pie maritam, prolis expertem diu, / faciet perenni fertilem de semine" (vv. 64-66). ${ }^{19}$ For the time being, we may pass over the passage's theological connotations. We are left with some suggestive words - 'casam;' 'cordis,' 'animam' - symbols of the Innenwelt bequeathed to so many subsequent generations of writers. The special significance that these core signifiers hold in store for the purpose of our study will become apparent presently.

The second characteristic of egocentrism consists in a special dialectic between the microcosm and the macrocosm: absorbed in his own psychomachia, the lover's persona enhances the awareness of his unique condition even as he realizes his vivencia in the economy of a supernatural order, identified, more often than not, with the plans of

${ }^{19}$ I have availed myself of $H$. J. Thomson's edition and translation in two volumes (Cambridge: Harvard UP, 1949-53). Also, I have consulted Psychomachia, ed. I. Rodríguez, trans. José Guillén (Madrid: Biblioteca de Autores Cristianos, 1950). 
Divine Providence. I intend to show that it takes a poet of unquestionable genius - the Valencian Ausiàs March (1397-1459), illustrious lyricist of the first half of quattrocento - to provide us with a comprehensive and profound treatment of this symbiosis between the individual and the cosmos. ${ }^{20}$

The breadth and depth of March's vision bring to the fore yet another trait of egocentrism worthy of our consideration. As I have shown elsewhere, ${ }^{21}$ this has to do with March's constant preoccupation, not to say obsession, with truth and sincerity. As a result, March develops strategies of authentication in order to validate a fresh outlook on the lover's condition. Thus, he parallels in aesthetic terms the new wave of humanism heralded particularly by Lorenzo Valla's revolutionary ideologies. ${ }^{22}$

Finally, Ausiàs March uncovers a fourth aspect of egocentrism. His assertion of the genuine nature of his love experience assumes an extrovert dimension best illustrated by the force of the outward trajectory of the dramatic monologue. This dramatic epiphany of the lover's persona is akin to the phenomenon which Clarke, apropos of Mena's allegorical presentation of the combat between Reason and the vices, calls "display" (Allegory, 108). Demonstrably, March goes much further than does Mena in underscoring the drama, the nucleus of the theater, engendered by his allegorizations of the various intellective and emotive

${ }^{20}$ For March's extant cants, see Rafael Ferreres's updated edition, complete with a translation of those poems into Castilian (Obra poética completa, 2 vols., Clásicos Castalia, 99-100 [Madrid: Castalia, 1979-82]). See, also, the translations of March's poems into Castilian by Arthur Terry (in prose) (Selected Poems, Edinburgh Bilingual Library, 12, [Austin: U Texas P, 1976]) and by Purificació Ribes and Dominic Keown (in verse) (Selecció de poemes/Selected Poems II, ed. M. A. Conejero [Valencia: Fundación Instituto Shakespeare, 1989]).

21 "Ausiàs March and the 'Truth' of the Troubadours," in Studia in Honorem M. de Riquer, ed. Lola Badia, et al. (Barcelona: Quaderns Crema, 1986), pp.111-132.

22 See: Ciriaco Morón Arroyo, "A Historical Revolution: Lorenzo Valla's Attack on Scholasticism," in Acta VIII: The Late Middle Ages, ed. P. Cocozzella (Binghamton: The Center for Medieval and Early Renaissance Studies--State University of New York at Binghamton, 1984), pp. 23-45; Maristella de Panizza Lorch, "Virgil in Lorenzo Valla's Dialogue On Pleasure," in Acta IX: The Early Renaissance, ed. A. L. Pellegrini (Binghamton: The Center for Medieval and Early Renaissance Studies--State University of New York at Binghamton, 1985), pp. 3356. 
faculties of the psyche. In so doing, Ausiàs March helps us better to understand the linkage between, on the one hand, the lyricism prevalent in the Iberian Peninsula - in the domains of both Castilian and Catalan - and, on the other hand, the theatrical literature, properly called, by such authors as Gómez Manrique, Juan del Encina, Gil Vicente, to name some representative figures - linkage that, as Ronald Surtz points out, is widely recognized by hispanists (The Birth of a Theatre, 30-31).

A contrast between Mena's and March's use of allegory highlights the Valencian poet's outstanding contribution to the advancement of the egocentric text previous to Celestina. By his definition of the precincts of the persona, Juan de Mena penetrates the enclosure of selfhood. He reduces the image of the casa, which Prudentius aptly used as a metaphor, to the state of a residual - a shadowy symbol of the "yo." No matter how imaginatively Mena explores the dimensions of the "yo," no matter how cleverly he recaptures the Stoic notion of the pathoi or affectus in their primordial strife with Reason, ${ }^{23}$ there is a considerable if not insurmountable gap between his text and Rojas's auto, especially as embodied in those papeles of the docto varón. Ausiàs March as an intermediary figure bridges that gap and corroborates Clarke's insights into the affinities between Mena's and Rojas's respective textuality. March allows us a rewarding insight into the most intimate core of the individual consciousness.

In his magnificent Cant $X$, but one of the many examples that could be adduced for our purpose, he reaches back to the Psychomachia and devotes the functions of the metaphor and allegory to produce lifelike depictions of the human experience. ${ }^{24}$ Robert Archer's brilliant analysis of the poem makes us realize that in it Ausiàs develops a special aesthetic of incremental cohesiveness: the image (a hybrid of metaphor and allegory) gradually becomes sharper and its meaning clearer to the extent in which the tension within the author's persona becomes more

${ }^{23}$ For an enlightening study of Stoic principles and their influence upon Celestina in particular and the kindred Castilian literature of the XV-century in general, see L. Fothergill-Payne, Seneca and 'Celestina' (Cambridge: Cambridge UP, 1988).

${ }^{24}$ Throughout my discussion, for references to and quotations from Ausiàs's cants, I make use of Ferreres's edition (n28, above). For Cant X, see I: 166-169. 
and more pronounced. ${ }^{25}$ In terms of the poem's striking imagery, all this finds an ontological correlative in the war between the king (that is, the personal ego) and "l'enenmich" (Amor as the anti-ego), who has been able to take possession of the king's three cities (symbols of the corresponding faculties of intellect, memory, and will) thanks to the collaboration of a "soldader" ('mercenary': a figure of the lady's "cors" mentioned in v. 21). Acting, in all probability, in unison with the Stoic or, specifically, the senequista tradition, Ausiàs March, in effect, adumbrates a symbiosis of mutual alterity. The aforementioned ego and anti-ego are the reciprocal others. In them March brings into view two existential modes: $A$ confronts itself reflected, though in a splintered state, in $B$. This dialectic of integration and disintegration, so eminently illustrated in Cant $X$, remains a constant throughout March's production: it constitutes his outstanding contribution to the textuality of egocentrism.

From Cant $\mathrm{X}$ it appears that Ausiàs March is moving decidedly toward refurbishing the roles of Reason and Will, protagonists of his own version of the psychomachia. Here, much more distinctively than in works like Mena's Debate, Reason becomes an agent of integration and Will the fomenter of the divisive forces unleashed by Amor in collusion with the entourage of pathoi. The presence of these two roles is well in accord with Miquel Sobrer's recognition, throughout March's production and especially in Cants 69 or 105, of what Sobrer calls "la consciència d'una ment en lluita constant amb ella mateixa."26 I would fully agree with Sobrer's vision of a "schizoid" phenomenology within the poet's persona - "Aquest s'escindeix en analitzador i analitzat" (33) - a splitting of the self manifested in the "la divisió interna" (38), "la partició de la personalitat" (65), and culminating in an overall effect of a hall of mirrors ("cambra emmirallada" [73]). Also, I would underscore, as does Sobrer, the assertion of a rational factor, identified with the "analitzador," la "veu dominant," the "personalitat narrativa del mateix jo del poeta" (33-35), or the spectator of the auto-introspection:

Perquè la introspecció sigui possible, més ben dit, perquè sigui imaginable (car es tracta d'imaginar-la més que no

${ }^{25}$ The Pervasive Image: The Role of Analogy in the Poetry of Ausiàs March, Purdue University Monographs in Romance Languages, 17 (Philadelphia: John Benjamins, 1985), pp. 102-105.

${ }^{26}$ La doble soledat d'Ausias March (Barcelona: Quaderns Crema, 1987), pp. 39-40. Further page references will appear in the text. 
de portar-la a terme), ens hem de partir a priori en espectador i espectacle. (65)

Evidently, Sobrer has in mind a principle of order or unity, which impels a constant drive toward the expression of an elusive synthesis. The result is a sense of tension, a distinctive trait of March's poetry, which, following Sobrer's analysis, we see coming to a head in the so-called Cant espiritual, March's Cant 105:

El poema s'insereix entre contraris, passa la maroma entre opostos tot esforçant-se, diríem, cap a una delimitació, cap a una decisió. El poema vol el resultat, la síntesi, la veritat. (46)

To summarize: A review of the vast body of literature, chiefly represented by the cancioneros, the novelas sentimentales, and the cants of Ausiàs March, brings to light a special kind of text, a study of which promises a fresh outlook on the genesis of Rojas's Celestina. So far I have provided a general profile of such a text determined by an unmistakable egocentric orientation. From my preliminary discussion it becomes apparent that the egocentrism in question is defined by a notion of inner space. This, in turn, involves a distinctive vision of a persona as an immanent microcosm in symbiotic interaction with a transcendental order of things. Other egocentric qualities that come to our attention are the various strategies, devised by the literary persona to authenticate the lover's individual experience and, stemming from those strategies, the proto-dramatic phenomenology, invested with the dynamic of "display" or epiphany.

The phenomenon of egocentrism continued well beyond Ausiàs March's lifetime. Three writers in particular - namely, El Comendador Escrivá, Francesc Carrós, and Francisco Moner - who flourished in the second half of the fifteenth century, catch our attention because of their own excursions off the trail blazed by the Valencian master. Only Escriva has attained a measure of the renown that all three authors and, we may add, many of their contemporaries, justly deserve. In his seminal sketch of the Comendador's career, Martí de Riquer identifies him as the Valencian Joan Ram Escrivá de Romaní and situates him in the literary circle made up of Bernat Fenollar's friends. ${ }^{27}$ Escrivá played a prominent role in international politics in the service of Ferdinand the Catholic. He figured in the Neapolitan court in the entourage of Fernández de

${ }^{27}$ See Martí de Riquer, Història de la literatura catalana (Barcelona: Ariel, 1964), III: 321-364, especially 357-362. 
Córdoba, el Gran Capitán. ${ }^{28}$ Menéndez y Pelayo, who also devotes to the Comendador some enlightening comments, tells us that he was "Maestre Racional del Rey Católico y su Embajador en 1497 ante la Santa Sede." ${ }^{29}$ About Carrós we know very little besides the fact that he, like Escrivá, was Valencian. The scarce archival data that José Reyes-Tudela integrates into his informative outline of Carrós's biography ${ }^{30}$ confirm Menéndez y Pelayo's inclusion of this author within "la escuela valenciana del siglo XV." ${ }^{\text {"31 }}$ In contrast with Escriva and Carrós, Moner is Catalan to the marrow of his bones. He was born in Perpignan toward the end of 1462, was educated in the court of John II of Aragon, and spent his most productive years (ca. 1485-1490) in Barcelona, in the household of the Cardonas, Catalonia's aristocratic family par excellence. His short life of barely twenty-eight years also includes a brief residence in France (1479-1481), a stint in the military (1481-1485), and a few months of monastic seclusion (1491-1492). From a laconic statement penned by his own cousin, we learn that Moner died a suspicious death ("no sin misterio") on the very day of his profession as a Franciscan friar. $^{32}$

The relevance of Escrivá's, Carrós's, and Moner's contributions may be assessed on the basis of the recent publication of their literary output. Escrivá's intriguing Querella ante el dios Amor is included in Teatro medieval, the noted anthology of Spanish medieval theater, compiled by Fernando Lázaro Carreter (see n17). Carrós's extant production and most of Moner's works have been edited, respectively, by José Reyes-Tudela

${ }^{28}$ Riquer, pp. 359-361.

${ }^{2}$ Origenes de la novela, ed. E. Sánchez Reyes, 4 vols., Ed. Nacional de las Obras Completas de Menéndez Pelayo, 13-16 (Santander: Aldus, 1943), II: 56.

${ }^{30}$ See "Las obras de Francesch Carroç Pardo de la Casta, autor bilingüe valerıciano del siglo XV: edición, estudio y notas," Diss. State Univ. of New York at Binghamton 1980, pp. 1-16.

${ }^{31}$ Antología de poetas líricos castellanos, ed. E. Sánchez Reyes, 10 vols., Ed. Nacional de las Obras Completas de Menéndez Pelayo, 17-26 (Santander: Aldus, 1944-45), III: 404. See, also, Riquer, pp. 246-249.

${ }^{32}$ For a detailed account of Moner's life, see P. Cocozzella, Introd., Poemas menores, Vol. I of Obras castellanas, by Francisco Moner, ed. P. Cocozzella, Hispanic Literature, 2 (Lewiston, NY: Edwin Mellen Press, 1991), pp. 3-38. 
and Peter Cocozzella. ${ }^{33}$ The merit of the three writers we are considering here and, we suspect, of many others that remain to be discovered, resides precisely in their continuation of the Ausiàs-March tradition. In fulfilling their role as continuators, they strive for the originality of adapting the lyrical expression of the fifteenth century the quintessence of Ausiàs March's "mighty line" - to the exigencies of a theatrical presentation or performance. Demonstrably, such representative pieces as Escrivás aforementioned Querella, Carrós's Regoneixença e moral consideració contra les persuacions, vicis e forces $d^{\prime} a m o r,{ }^{34}$ and Moner's La noche ${ }^{35}$ attest to an evolution from lyricism to drama and provide a concrete evidence for the existence of a theatrical text, which Lázaro Carreter calls "auto de amores," a title he derived from the exordium of Triste deleytaçión, a prototypical novela sentimental. ${ }^{36}$ In his pioneering study Lázaro Carreter highlights the salient features of that "auto".

${ }^{33}$ For Carrós's works see Reyes-Tudela's aforementioned edition (n30 above). For Moner's production see the following: "The Two Major Prose Works of Francisco de Moner: A Critical Edition and Translation," ed. and trans. P. Cocozzella, Diss. Saint Louis U. 1966; Obres catalanes, ed. P. Cocozzella, Els Nostres Clàssics, 100 (Barcelona: Barcino, 1970); Poemas menores, Vol. I of Obras castellanas, ed. P. Cocozzella, Hispanic Literature, 2 (Lewiston, NY: Edwin Mellen Press, 1991); Poemas mayores, Vol. II of Obras castellanas, ed. P. Cocozzella, Hispanic Literature, 3 (Lewiston, NY: Edwin Mellen Press, 1991).

${ }^{34}$ The text of Carrós's masterpiece is available, also, in Novel tes amoroses $i$ morals, ed. Arseni Pacheco and August Bover i Font, Les Millors Obres de la Literatura Catalana, 73 (Barcelona: Edicions 62, 1982), pp. 158-191.

${ }^{35}$ See La noche, in "The Two Major Prose Works of Francisco de Moner: A Critical Edition and Translation," ed. and trans. P. Cocozzella, Diss. Saint Louis U. 1966, pp. 67-203.

${ }^{36}$ Lázaro-Carreter, Teatro medieval, pp. 68-70. The novela opens with a firstperson account of how the narrator became an author. Excerpted from Michael Gerli's edition, the crucial passage reads as follows: "[V]enido a conocimiento mío, ahunque por vía indirecta, un auto de amores de una muy garrida e más virtuosa donzella y de hun gentil honbre, de mí como de sí mismo amigo, en el tiempo de cinquenta y ocho, concorriendo en el auto mismo hotro gentil honbre y duenya madrastra de aquélla, yo, consideradas las demasiadas penas y afanes que ellos hobedeciendo amor procurado les avía, quise pora siempre en scrito pareçiesen" (Triste deleytaçión: An Anonymous Fifteenth Century Castilian Romance, ed. M. Gerli [Washington, D.C.: Georgetown UP, 1982], p. 1; emphasis mine). 
It bears considering that Escrivá, Carrós, and Moner lived in circumstances that compelled each to become, in his own way, a bilingual writer. In fact, the extant production of each writer contains significant samples both in Castilian and in Catalan or, as the case may be, in the Valencian brand of Catalan. It is beyond the province of this essay to investigate the modes of bilingualism that came to bear upon the production of these authors - especially, say, upon the aforementioned Querella, Regoneixença, and La noche. For the time being it will suffice to bear in mind that the obvious differences exhibited by these pieces are a reflection of those modes. Querella and $L a$ noche, both written in Castilian - one in verse and the other in prose - manifest Escriva's and Moner's bold experimentation in a foreign language, privileged more and more by the vagaries of politics. Regoneixença, by contrast, written in its author's native Valencian in the exuberant manner of a highly ornamented prose, which came to be known as "valenciana prosa," demonstrates the sophistication and sprezzatura of a man of letters, who already has proven his talent by amassing a sizable collection of poems in Castilian, the language of prestige.

Lest we dwell on half truths, we hasten to add that beneath obvious differences, Querella, Regoneixença, and La noche exhibit not so obvious but no less real similarities. In two studies I have attempted to show that what these compositions have in common is the subtext of the auto de amores. ${ }^{37}$ By simple deduction, then, we may come to the realization that the auto is a product of bilingualism. Even by a cursory comparison we may discover, also, that Moner strives, much more intensely and persistently than do Escrivá and Carrós, for a text enhanced by introspective depth, comprehensive scope, and, above all, by the dynamism of a superspectacle. Moner's fascination for the spectacular and for the attendant theatrical qualities has been duly recognized by Surtz, who includes Fray Francisco's intriguing Momería in his anthology, Teatro castellano de la Edad Media (at pp. 145-149).

Momeria is spectacular enough. Six momos in the guise of woebegone lovers step out of a huge wooden structure fashioned in the shape of a cygnet. Even as they dance in a group at a slow compass, they intone, one by one, mournful songs about love's labors lost and the belle dame sans merci. The author does not participate in the enactment of

${ }^{37}$ See Cocozzella, "El Comendador Escrivá's Legacy: The Valencian Auto de Amores of the Fifteenth Century," Cincinnati Romance Review 11 (1992): 10-25; and "Fray Francisco Moner's Dramatic Text: the Evolution of the Spanish Auto de Amores of the Fifteenth Century," Revista de Estudios Hispánicos 26 (1992): 21-36. 
the routine: we may picture him aloof as a spectator absorbed in contemplation. What with all its stage presence, Momeria represents only a first step in Moner's involvement with the theater. His crowning achievement would be the development of an authorial persona that takes center stage in the inner theater of the lover's psyche. The growth of Moner's persona in the role of "lover-agonistes" marks the author's admirable advances, throughout his career, along the road of egocentrism.

It is in his lifelong, steady progression of egocentrism that Moner simply outdistances his contemporaries. Lázaro Carreter summarizes his comments on Escrivá's Querella with the following statement:

También éste [Escrivá] nos cuenta sus atroces dolores de amor, intenta dormir, se querella en verso contra el Amor, dialoga con él, es trasladado misteriosamente a un campo florido, por el que discurre un río, embarca en una nave, llega al reino del Amor (...) Son tópicos literarios del momento. (70)

By and large, these comments are applicable to Carrós's Regoneixença as well. As for Moner, we cannot help noticing the profound transformation he brings about in the hackneyed tópicos. A case in point is his ingenious handling of the mártir de amor in Sepoltura d'amor, one of his major poems written in Castilian. ${ }^{38}$ In this visionary composition he revamps the commonplace depiction of the anguished lover by canonizing and incarnating the latter in the literary portrait of an artistic alter ego: Moner's own poetic persona. In the final analysis, Moner writes the elegy - complete with the funeral ceremonies and the panegyric - pertaining to the lover he envisages himself to be or, at least, to become. He, accordingly, proceeds to project his vivencia into a personalized allegory, appropriately called Esperiencia. At a crucial moment of the ceremonial (vv. 639-94), Esperiencia, who is one of the three female celebrants of the funeral mass, treats the epitomized account of Moner's life ("[l]'ystoria de quyen muryó") as a natural sequel of the Gospel reading. Moner converts his existence - the quintessential plot of his life - into a text, for which he devises a literary correlative: the allegorization of a female persona. By sacralizing that text, he gives a new twist to the analogy between the lover and the saint, one of the "tópicos literarios del momento," which

${ }^{38}$ Obras castellanas I: 131-194. 
Lida de Malkiel in one of her seminal studies entitles "hipérbole sagrada. ${ }^{.39}$ By virtue of his elaborate handling of the egocentric motif, Moner substantiates and validates the "tópico" that Lázaro Carreter would cavalierly dismiss: "Son tópicos literarios del momento (...)" (70).

It is in La noche, to be sure, where Moner's egocentrism achieves its most luxuriant blossoming. In $L a$ noche Moner recaptures the aforementioned fourfold dimensions of March's self-conscious textuality: the microcosmic "I," the macrocosmic compendium, the validating truth, the dramatized display. In other words, he orchestrates into one composition, impressive in its complex structure, the main qualities that we have discussed apropos of Ausiàs March: the introspective penchant, the universal projection, the verification of the author's insight by the confrontation of individual experience, the dramatic flair that grants to that experience "a local habitation and a name" upon the stage. Above all, in La noche Moner fashions his own auto de amores by focussing upon the primordial dynamism of the split self - the existential conflict between the intellective and emotive faculties, which represent, respectively, the integrating and disintegrating forces portrayed in the allegories of Reason and Will.

As we approach the conclusion of our discussion, it is well to summarize the basic steps of our argumentation. We have departed from current Celestina criticism in interpreting Rojas's own remarks as a lead not to the identification of a docto varón but to the definition of the nature of the docto varón's papeles, from which Rojas drew his inspiration. In particular, Rojas's mention of Juan de Mena has motivated us to profile the salient traits of an introspective text, eminently exemplified by Mena's Debate de la Razón contra la Voluntad. We have argued that Mena's "egocentrism," which finds many kindred statements throughout the numerous Castilian cancioneros of the first half of the fifteenth century, achieves a truly comprehensive expression in the production of Mena's contemporary, Ausiàs March, the incomparable bard from Valencia. We have seen how, in the second half of the fifteenth century, bilingual authors like Escrivá, Carrós, and Moner capitalized upon the suggestive metaphysical and psychological dimensions of March's aesthetic. In striving to realize the untapped potential of March's lyricism for a theatrical performance, they elaborated a literary mode, which may be called "auto de amores." Worthy of special mention is Moner's La noche, which marks the transferal of the auto in question from the domain of

39 "La hipérbole sagrada en la poesía castellana del siglo XV," Revista de Filología Hispánica 8 (1946): 121-130. 
Catalan to that of Castilian. With La noche, then, we have come full circle. Moner's "egocentrism" approaches the realm of creativity of Rodrigo Cota, the other docto varón mentioned by Rojas.

It is Rojas himself, then, who has provided the bearings for our journey from Mena to Cota, thus warranting, in the process, our excursion from Ausiàs March to Moner. The excursion has allowed us to trace the transition from lyricism to drama, from the inner world of the psyche to the exterior space essential for the theater. In his artistry driven by the twists of conceits, Moner hits upon a paradigm of this evolvement of dramatic action. In one scene of Sepoltura d'amor (vv. 120-129), as the author gazes upon the funeral of his own persona, Manzilla, one of the three female priests, begins to chant a fragment of one of Moner's poems, a motet written on slip of paper, which she has had to dislodge from the mouth of the poet's inert body. Here, as Manzilla passes from silence to song, the literally "dead letter" of the lyric mutates into a ritualistic gesture, which bespeaks the birth of a mise en scène.

An emblem of a paradoxical "rhetoric of silence," the curious incident of Sepoltura d'amor is, of course, but a token index of a consistent pattern - the pattern of the gradual coming to light of the inner agon of a psyche wrecked by the ravages of passionate love. Our present discussion shows that writers like Ausiàs March and Moner bequeath to authors of subsequent generations this agon as the epitome of egocentrism and as the Ursprung of theatricality. Our research shows, also, that the egocentrism in question stems, ultimately, from Prudentius, specifically from Psychomachia, vv. 59-68, a passage we have commented upon already. The "casa" mentioned, as we have seen, in this crucial source adds, I believe, new connotations to the leitmotif that Stephen Gilman discerns in the wondrous orchestration of Celestina:

La situación vital básica en La Celestina es la domesticidad. La vida es vivida dentro de casa en cerrada convivencia. La acción principal tiene lugar en tres casas: el domicilio de soltero de Calisto, con sus criados de excesiva confianza; la residencia familiar de Melibea; y la casa, burdel e infernal depósito de Celestina (...). Cada uno de estos establecimientos domésticos es concebido como una especie de célula de intimidad. $^{40}$

${ }^{40}$ Introd., La Celestina: Tragicomedia de Calisto y Melibea, ed. D. S. Severin (Madrid: Alianza, 1990), p. 17. 
We may add that, in the light of the subtext emanating from Prudentius, the "casa" available to the docto varón and to Rojas is a figuration of primordial theatricality, a concretization of the ambience of egocentrism.

We believe that our own perception of "casa" as "célula de intimidad," to borrow Gilman's happy phrase just quoted, sheds light on the dramatization of a fundamental aspect of the lover's plight in Celestina - an aspect which eludes even such a farsighted and meticulous critic as Lida de Malkiel. After her admirable review of the various currents that come to bear upon one of the crucial issues in the art of Celestina, she concludes:

No en el teatro romano, sino en la comedia elegíaca y en la novela sentimental del Renacimiento, heredera de una larga tradición clásica y medieval, se adiestraron los autores de La Celestina en la pintura de conflictos anímicos, dejando muy atrás a sus modelos en variedad y hondura psicológica. ${ }^{41}$

To the list of influences amply documented by Lida de Malkiel we may add, now, the egocentric auto de amores, born of the dynamic of the "split self."

There is little doubt that, in its demarcation of psychic space, the egocentric text reflects a protean mode of existence, which eludes the analysis of critics such as Antonio Sánchez Sánchez-Serrano and Maria Remedios Prieto de la Yglesia. They look for authentic authorship and find a patchwork, put together, they presume, by Rojas on the basis of contributions from various authors: Encina, Proaza, possibly some other writers and, of course, Rojas himself. Our approach, on the contrary, confronts us with the moment-to-moment mutability, the existential complexity of a self-conscious or even subconscious state - the mind-set, say, of a perturbed Calisto or a shaken Melibea - at odds with the cohesiveness and logical consistency expected by Sánchez and Prieto. ${ }^{42}$ Whether considered a comedia or a tragicomedia, Celestina is, after all, a textual meeting ground: it is the ontologic correlative of various "selves," driven to a dialogue one with the "other" by passions, greed, and concomitant self-destructive pathoi.

${ }^{41}$ La originalidad artística, p. 132.

42 For the long list of the "contradicciones" they perceive in Celestina, see their study (n11), pp. 41-66. 
Underlying even the "arte dialógico" so eloquently and cogently analyzed by Gilman in his aforementioned The Art of 'La Celestina', the aforementioned dynamic of the split self impels the dialogue of self to self, the primordial dialectic of alterity connnatural to human consciousness. Foreshadowing the notion of "monodiálogo" that Unamuno would discover at the dawn of the existentialism of our age, the egocentrism I have discussed in this essay corroborates the insights of critics like Giulia Adinolfi apropos of the dramatic nature of Celestina. Probing the depth and lifelike intimacy that we instinctively perceive in the characters of Celestina, Adinolfi is able to make out the distinctive features of Rojas's egocentric creativity. We would fully concur with the following statement of Adinolfi:

Semejantes personajes no adquieren vida, carácter, individualidad por las acciones de que Rojas les hace protagonistas, sino por las justificaciones complejas e introvertidas que necesitan para llegar a sus decisiones. Por eso, los momentos de tensión más aguda, los nudos mismos a través de los cuales se articula el drama de $L a$ Celestina, son los monólogos, largas páginas, a veces, de alucinante iluminación psicológica. ${ }^{43}$

It is this iluminación that I have tried to promote and confirm in this essay.
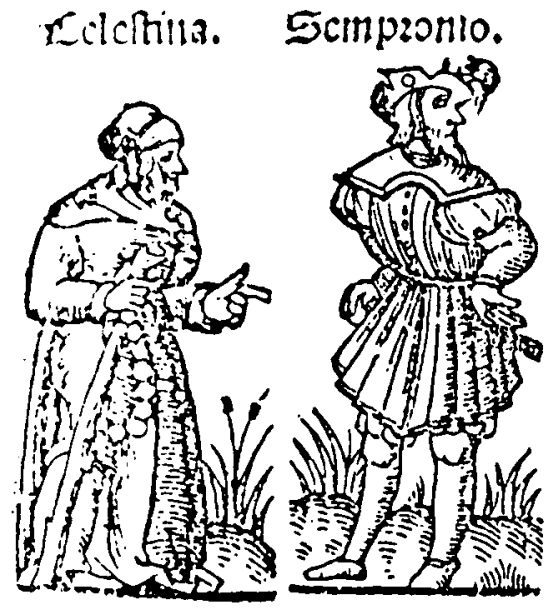

Sevilla: J. Cromberger, 1535

${ }^{43}$ Quoted in Lida de Malkiel, La originalidad artística, 124-125, n3. 